\title{
Stimulation of soluble guanylyl cyclase protects against obesity by recruiting brown adipose tissue
}

\author{
Alexander Pfeifer", Jennifer Etzrodt, Linda S Hoffmann \\ From 7th International Conference on cGMP Generators, Effectors and Therapeutic Implications \\ Trier, Germany. 19-21 June 2015
}

\section{Clinical background}

Obesity has reached pandemic dimensions and novel pharmacological therapies are urgently needed. Obesity is characterized by excessive fat storage in white adipose tissue (WAT), because of a positive energy balance. In contrast to WAT, brown adipose tissue (BAT) dissipates energy and produces heat - a process known as nonshivering thermogenesis. To identify novel BATcentered antiobesity therapies, we studied the role of soluble guanylyl cyclase (sGC) in BAT. sGC produces the second messenger cyclic GMP (cGMP) after stimulation with nitric oxide.

Here, we used a small molecule that stimulates sGC in a heme-dependent manner. Treatment of mice with the sGC stimulator during a high fat diet protected against weight gain and improved metabolic changes. Notably, stimulation of sGC induced weight loss also in already established obesity. Mechanistically, the sGC stimulator enhanced expression of thermogenic genes and induced "browning" (i.e. the expression of brown adipocytespecific markers) of murine and human adipocytes. sGC stimulation increased lipid uptake into BAT, and caused an increase in whole body energy expenditure.

\section{Conclusion}

Taken together, sGC is a potential pharmacological target for the treatment of obesity and its comorbidities.

Published: 2 September 2015
doi:10.1186/2050-6511-16-S1-A6

Cite this article as: Pfeifer et al: Stimulation of soluble guanylyl cyclase protects against obesity by recruiting brown adipose tissue. BMC Pharmacology and Toxicology 2015 16(Suppl 1):A6.
Submit your next manuscript to BioMed Central and take full advantage of:

- Convenient online submission

- Thorough peer review

- No space constraints or color figure charges

- Immediate publication on acceptance

- Inclusion in PubMed, CAS, Scopus and Google Scholar

- Research which is freely available for redistribution
C Biomed Central 